\title{
PORTRAIT RABINDRANATH TAGORE AS A PATRIOT FROM HIS LITERARY WORK
}

\author{
Ms. Benzir Katara \\ \& \\ Dr. Ashutosh A Pathak
}

\begin{abstract}
:
In this research paper the researcher will make an attempt to study problem that why Rabindranath Tagore is recognized as a Patriotic through their selected work of literature and why he has taken active in Indian freedom Movement.
\end{abstract}

Key words: Patriotic poet, patriotism, Indian Poem

Patriotism, like beauty and goodness, is one of those things that we can never rigidly define, because though everyone has some rough notion of its meaning, we doubt if anyone has ever yet grasped its full meaning. We may, provisionally, describe it as the love that a man bears for his country, but this is to fly from one difficulty into two, for love is as infinite as God, and as for country, it is not always easy to tell the point at which patriotism begins and treason ends. We may not deny the title of patriot to men so various as Shakespeare and Addison, Cromwell and Nelson, Chatham and Castlereagh. But what shall we say of less obvious cases, of Walpole, of Charles James Fox, of John Bright? Can an Englishman be a patriot who prays for the defeat of our arms, like the youthful Lake Poets; or when he is receiving the pay of the foreigner, like Algernon Sidney; or when he is ready to back his domestic policy by foreign invasion, like the leaders of our Whig Revolution? These are cases of infinite delicacy, and not to be compassed by any definition. 
Towards Excellence: An Indexed, Refereed \& Peer Reviewed Journal of Higher Education / Ms. Benzir Katara \& Dr. Ashutosh Pathak / Page 135-138

There is a prevailing misconception that Rabindranath Tagore was not robust enough in his opposition to British rule in India. It is even thought in some circles, that Tagore composed his Janaganamana Adhinayaka', which has been the national anthem of India for nearly 70 years, as an eulogy for King George V on the occasion of the King Emperor's visit in 1911 even though history has well recorded and even Tagore also offered numerous clarifications to establish that he composed the song for an Indian National Congress session. Again some people still think that Tagore won his Nobel Prize for Literature in 1913 due to his connections with the famous English poet of the time, W.B. Yeats, and the influence Yeats peddled in this regard to clinch the Prize for Tagore. A retired Supreme Court judge even recently called Tagore a -British puppet\| ignoring the fact that Tagore renounced the Knighthood given to him by the British monarch in protest against the Jallianwalabagh massacre of April 1919. The letter, written by Tagore to the Viceroy returning the Knighthood, remains a legend in the annals of protest literature. However, semi-ignorant and motivated people continue to cast a slur on Tagore due to reasons best known to them.

The sources of Tagore's poetry are eternal and elusive. In The Religion of Man Tagore defines human life as - the ceaseless adventure to the Endless Further.l This seems to be true of his poetry also. The unique search for the infinite that his poetry records with honesty and pathos has been rare. If the defense of this poetry were needed, his later poems are the most mature in Tagore's life and can claim an independent value of its own. Firstly, while revealing new tendencies it contains a summary of nearly all his earlier styles and attitudes. It is a miniature and more than recapitulation of the past and it is an anticipation of the future. Secondly, it is characterized by experiences and experiments that are unusual even for Tagore. These poems have experiences connected with the illness of 1937 and 1940 and are filled with crises. The crisis in an artist's life may perhaps be a gain for his art. In his poems dealing with this phase of his awareness, of society, politics and war, the silent folks of the land, Tagore reaches a new level of insight and humility.

There were many individuals behind the South Asian Independence movement who contributed many unique and passionate ideas about how much independence India should have and how to achieve that independence. One of these individuals was Rabindranath Tagore. Although Tagore 
Towards Excellence: An Indexed, Refereed \& Peer Reviewed Journal of Higher Education / Ms. Benzir Katara \& Dr. Ashutosh Pathak / Page 135-138

was good friends with Mohandas Gandhi, he disagreed with Gandhi‘s political ideas concerning Indian independence. Rabindranath Tagore denounced British imperialism, yet he did not fully support or agree with Gandhi and his Noncooperation Movement. He viewed British rule as a symptom of the overall — sickness\| of the social — diseasell of the public. Rabindranath Tagore was born in 1861 and was the youngest son of Debendranath Tagore who was a leader in a Hindu religious sect known as the Brahmo Samaj. He was educated at home until he was seventeen when he was sent to England for schooling. In his adult years, he was involved in many different endeavors such as managing his family's estates. Managing these estates brought him in touch with common humanity and he made him more interested in social reforms. He was also a very influential figure in literature and music and later shared some of his political and social philosophies through these methods. Tagore was a Romantic poet, song-writer, novelist, along with being an Indian nationalist and idealist. He was the first Asian recipient of a Nobel prize that he achieved for his works in the arts. Rabindranath Tagore's political views were very mixed. He generally denounced British imperialism and spoke out against it in some of his writings. In his writings, he also voiced his support of Indian nationalists. Although he supported nationalism, Tagore did not support the element in Gandhi's Noncooperation Movement called the Swadeshi movement which was an economic strategy that aimed to remove the British from power in India by using principles of Swadeshi such as boycotting British products, and improving production in India. One of the main reasons that Tagore was against this movement was because although it was effective in resisting British control, the movement did not take into account the great losses that Muslim traders in India would endure as a result of the movement. In one of his novels, Tagore depicts Muslim traders being harassed by the public who forced them to burn their stocks of British goods. In addition, Tagore was outraged by the British proposal to partition Bengal and argued that instead of partitioning Bengal, what was needed was a self-help based reorganization of Bengal. Another one of Tagore's contradicting political beliefs was that he denounced nationalism because he believed that a nation was the formation of a population that assembles for a specific purpose and that purpose is usually a selfish purpose. He wrote many pieces and delivered lectures over his beliefs about nationalism and especially the examples of nationalism that he saw in his extensive travels and the growing nationalism he observed in Germany prior to World War II. Despite voicing his negative opinions about the nature of nationalism, Tagore wrote many songs praising the Indian independence movement. He 
defies both categories of politics because, although he warned against the oppressive nature of colonialism, he also warned against excessive revolutionary nationalism. Tagore withdrew from the forefront of the Indian nationalism movement when he observed the development of revolutionary nationalism. Specifically, Tagore witnessed the violent murder of a woman and child by an eighteen year old nationalist named Khudiram Bose. Bose had accidently killed them when he was attempting to assassinate the British magistrate of Muzzafarpur, a town in the Indian state called Bihar. Tagore was appalled by the violence and came to the realization that the entire independence movement was becoming more violent as a whole. At the same time, Tagore rejected violence from the British as well and renounced the knighthood that had been given to him in by Lord Hardinge in 1915 in protest of the violent Amritsar massacre in which the British killed at least 1526 unarmed Indian citizens. The cornerstone of Tagore's beliefs and work is the idea that anti-colonialism cannot simply be achieved by rejecting all things British, but should consist of incorporating all the best aspects of western culture into the best of Indian culture. One of the most important ideas that Tagore contributed is that -freedom\| does not simply mean political freedom from the British; True freedom means the ability to be truthful and honest with oneself otherwise autonomy loses all of its worth. From his childhood in which he was part of an upper caste Bengali family subject to British colonialism, to his efforts as an adult during the independence movement, Rabindranath Tagore's philosophies and writings contributed a great deal to the independence movement by shaping the ideas and thinking of many other important figures such as the famous Indian nationalist Mohandas Gandhi.

\section{Conclusion}

This chapter represent the result of analysis based on the collected data and related review of literature. Based on the hypothesis the result shows the patriotism elements in Tagore's literature work. This chapter also covers the related incident which represents the Tagore's image as a patriotism.

Ms. Benzir Katara, Research Student, Calorax Teacher's University, Ahmedabad

\author{
Dr. Ashutosh A Pathak \\ Research Guide \\ Calorax Teacher's University, \\ Ahmedabad
}

